\title{
CHEMICAL AND SENSORY CHARACTERIZATION OF THE AROMA OF 'CHARDONNAY' MUSTS FERMENTED WITH DIFFERENT NITROGEN SOURCES
}

\author{
CARACTERIZAÇÃO QUÍMICA E SENSORIAL DO AROMA DE MOSTOS 'CHARDONNAY' \\ FERMENTADOS COM DIFERENTES FONTES DE AZOTO
}

\author{
Pedro Miguel Izquierdo Cañas ${ }^{1,2 *}$, Adela Mena Morales ${ }^{1}$, J.M. Heras Manso ${ }^{3}$, E. García Romero ${ }^{1}$, Miguel \\ Angel González Viñas ${ }^{4}$, Eva Sánchez Palomo ${ }^{4}$
}

\footnotetext{
${ }^{1}$ Instituto de la Vid y el Vino de Castilla-La Mancha IVICAM-IRIAF. Ctra. Toledo-Albacete s/n. 13700, Tomelloso (Ciudad Real).

${ }^{2}$ Parque Científico y Tecnológico de Castilla-La Mancha, Paseo de la Innovación, 1, 02006 Albacete.

${ }^{3}$ Lallemand Península Ibérica, Tomás Edison, 4, 28521 Madrid.

${ }^{4}$ Facultad de Ciencias y Tecnologías Químicas, UCLM, Avda. Camilo José Cela s/n 13071 Ciudad Real.
}

* corresponding author: Tel.: 034926 275772, e-mail: pmizquierdo@jccm.es

(Received 09.04.2018. Accepted 25.07.2018)

\section{SUMMARY}

This work studies the influence of two different nitrogen sources added to the must on aromatic series and sensory profile of 'Chardonnay' wines. Volatile compounds were classified into six odorant series and the total intensities for every aromatic series were calculated as sum of the OAV of each one of the compounds assigned to these series. Sensory profile was defined by quantitative descriptive sensory analysis. The fruity, floral and sweet series are the ones most strongly contributing to the aroma of 'Chardonnay' wines, independently of nitrogen source added. In general, the fortification of must with nitrogen source enhances the aroma intensity of wines, especially fruity and floral notes. Samples with organic nutrient presented greater aromatic intensity and more floral aromas than samples with inorganic nutrient. According to the results, the fortification of must with organic nitrogen enhanced the aromatic complexity of wines.

\section{RESUMO}

Este trabalho estuda a influência de duas fontes de azoto adicionadas ao mosto nas séries aromáticas e perfil sensorial de vinhos 'Chardonnay'. Os compostos voláteis foram classificados em seis séries de odorantes e as intensidades totais para cada série aromática foram calculadas como a soma do OAV de cada um dos compostos atribuídos a esta série. O perfil sensorial foi definido através de análise sensorial descritiva quantitativa. As séries frutada, floral e doce são as que mais contribuem para o aroma dos vinhos 'Chardonnay', independentemente da fonte de azoto utilizada. Em geral, a fortificação do mosto com azoto aumenta a intensidade do aroma dos vinhos, especialmente notas frutadas e florais. Amostras com nutrientes orgânicos apresentaram maior intensidade aromática e mais aromas florais que as amostras com nutrientes inorgânicos. De acordo com os resultados, a fortificação do mosto com azoto orgânico aumentou a complexidade aromática dos vinhos.

Key words: Chardonnay wines, yeast nutrition, odour activity values, aromatic series, sensory profile.

Palavras-chave: vinhos Chardonnay, nutrição de levedura, valores de atividade odorante, séries aromáticas, perfil sensorial.

\section{INTRODUCTION}

The aroma of wine is a complex equilibrium of volatile compounds originated from grapes (varietal and pre-fermentative aromas), secondary products formed during the wine fermentation (fermentative aromas) and ageing (post-fermentative aromas). The production of positive aroma compounds by the yeasts during alcoholic fermentation can be significantly influenced by oenological practices such as clarification, aeration, yeast strains, nutrient added and temperature of fermentation (Hernández-Orte et al., 2006; Torrea et al., 2011; Izquierdo-Cañas et al., 2014).

The nitrogen composition of grape musts affects growth and metabolism of yeast, fermentation rate,

This is an Open Access article distributed under the terms of the Creative Commons Attribution License

(http://creativecommons.org/licenses/by/4.0), which permits unrestricted use, distribution, and reproduction in any medium, provided the original work is properly cited. 
production of aromatic compounds, ethanol and glycerol and completion of fermentation (Bisson, 1991; Albers et al., 1996; Barbosa et al. 2012). When nitrogen levels are low, it is common practice in enology to supplement the must with diammonium phosphate (DAP), or yeast derivate nutrients to prevent problems related to nitrogen deficiency, slow/stuck fermentations and $\mathrm{SH}_{2}$ production (Vilanova et al., 2007). The main sources of assimilable nitrogen in grape must are $\alpha$-amino acids, ammonium and to a lesser extent peptides (Butzke, 1998).

This addition must follow some criterion, since the addition of large amounts of ammonium in the must can result in later problems. Wines with higher amounts of residual nitrogen have greater risks of microbiological instability and production of ethyl carbamate (Hernández-Orte et al., 2006, GardeCerdán and Ancín-Azpilicueta, 2008). When the must is poor in ammonium and amino acids, the wineries usually add ammonium up to approximately 140 $\mathrm{mg} / \mathrm{L}$, as $\mathrm{N}$, a concentration that favours the correct development of alcoholic fermentation (Bely et al., 1990), but the must continues to be poor in amino acids.

There have been some studies on the effect of the addition of nitrogenous nutrition (mainly addition of ammonium) on the formation of some volatile compounds (Hernández-Orte et al., 2006; Burin et al. 2015). Nevertheless, few have focused on the effect of adding different nitrogen nutrient type (inorganic and organic) on the aromatic complexity of young white wines.

In this work the changes in aroma compounds of 'Chardonnay' wines from La Mancha region elaborated with different nitrogen nutrient was studied by grouping in odorant series the odour activity values of the compounds exhibiting similar odour descriptions. It was also studied their relation with their sensory properties.

\section{MATERIAL AND METHODS}

\section{Fermentation assays}

Grapes from Vitis vinifera cv. 'Chardonnay' were fermented in experimental winery of the IVICAM in vintage 2016. The chemical composition of the must was as follows: ${ }^{\circ}$ Brix 20.25 ; total acidity $6.71 \mathrm{~g} / \mathrm{L} ; \mathrm{pH}$ 3.23; L-malic acid $3.42 \mathrm{~g} / \mathrm{L}$ and $Y A N 217 \mathrm{mg} / \mathrm{L}$.

After the grapes had been crushed and pressed, pectolytic enzymes Lallzyme C-MAX $1 \mathrm{~g} / \mathrm{hL}$ (Lallemand Inc., Montreal, Canada) were added to the must, which was decanted statically for $12 \mathrm{~h}$ at $15{ }^{\circ} \mathrm{C}$ and then distributed in nine stainless steels tanks of $50 \mathrm{~L}$ equipped with a wrap stainless steel cooling jacket and thermometer connected to a control temperature system. Three tanks were supplemented with inorganic nitrogen (diammonium phosphate DAP), other three tanks with organic nitrogen (Fermaid $\mathrm{O}{ }^{\circledR}$ Lallemand Inc., Montreal, Canada), and three thanks without nitrogen addition (control wines). Both nutrients were added to the must at a single time of the alcoholic fermentation (when the density of must was approximately $1060 \mathrm{~g} / \mathrm{L}$ ) at a dose of $400 \mathrm{mg} / \mathrm{L}$ each of the different nitrogen sources.

All fermentations were conducted with a temperature adjustment of $16^{\circ} \mathrm{C} \pm 2{ }^{\circ} \mathrm{C}$ using selected active dry yeast Lalvin QA23 ${ }^{\mathrm{TM}}$ (Lallemand Inc., Montreal, Canada). The fermentation was controlled by density monitoring. Subsequently, the wines were decanted and sulphited to reach a free $\mathrm{SO}_{2}$ concentration of $25.0 \mathrm{mg} / \mathrm{L}$ and, subsequently, stabilized cold at about $3{ }^{\circ} \mathrm{C}$, filtered through $0.2 \mu \mathrm{m}$ membranes, following standard procedures, prior to bottling and stored in a conditioned room kept at $10^{\circ} \mathrm{C}$ until chemical analysis and sensory evaluations were performed three months later.

\section{Chemical analysis}

O.I.V. Compendium of international methods of wine and must analysis, 2014 (OIV, 2014) were employed for the analysis of Total Acitidity (OIV-MA AS31301 - Potentiometric titration), ${ }^{\circ}$ Brix (OIV-MA AS-02 - Refractometry) and pH (OIV-MA AS-313-15 Potentiometry) in musts, volatile acidity (OIV-MA AS313-02 - Steam distillation and titration), glucose+fructose (OIV-MA AS311-02 - Enzymatic method), ethanol (\% v/v) (OIV-MA AS312-01B Distillation and electronic densimetry), $\mathrm{pH}, \mathrm{L}-\mathrm{malic}$ acid (OIV-MA AS313-11 - Enzymatic method), and succinic acid and glycerine (OIV-MA AS313-04 HPLC with an ion exchange resin column) in 'Chardonnay' studied wines.

\section{Volatile compounds analysis}

Major volatile compounds were analysed by direct injection into a HP-5890 gas chromatography with a FID detector, using a CP-Wax-57 capillary column (50 m x $0.25 \mathrm{~mm}$ i.d.; $0.25 \mu \mathrm{m}$ film thickness). One $1 \mu \mathrm{L}$ was injected in split mode, split ratio 1:25. Carrier gas was helium $(1.7 \mathrm{~mL} / \mathrm{min})$. The oven temperature program was: $43{ }^{\circ} \mathrm{C}$ for 5 minutes, 4 ${ }^{\circ} \mathrm{C} / \mathrm{min}$ to $100{ }^{\circ} \mathrm{C}, 20{ }^{\circ} \mathrm{C} / \mathrm{min}$ to $190{ }^{\circ} \mathrm{C}$, and $45 \mathrm{~min}$ at $190{ }^{\circ} \mathrm{C}$. Injector and detector temperature were 220 
and $280^{\circ} \mathrm{C}$, respectively (Sánchez-Palomo et al., 2006).

Minor volatile compounds were extracted using the method developed by Ibarz et al. (2006). Prior to solid-liquid extraction, 4-nonanol in final concentration of $1 \mathrm{mg} / \mathrm{L}$ as internal standard is added to the sample. Extracts were concentrated by distillation in a Vigreux column and under nitrogen stream to $100 \mu \mathrm{l}$ and then kept at $-20{ }^{\circ} \mathrm{C}$ until analysis.

A Focus GC-ISQ gas chromatograph equipped with quadrupole analyzer (Thermofischer) was used for minor volatile compounds analysis. A BP21 column (SGE) $50 \mathrm{~m}-0.32 \mathrm{~mm}$ internal diameter and 0.25 mm thick of Free Fatty Acid Phase (FFAP) (polyethylene glycol treated with nitroterephthalic acid) was used. Operating conditions were as follows. Oven temperature program was: $70{ }^{\circ} \mathrm{C}(5 \mathrm{~min}$. $)-1$ ${ }^{\circ} \mathrm{C} / \mathrm{min}-95{ }^{\circ} \mathrm{C}(10 \mathrm{~min})-2{ }^{\circ} \mathrm{C} / \mathrm{min}-200{ }^{\circ} \mathrm{C}(40$ $\mathrm{min})$. Injector and transfer line temperatures were 250 ${ }^{\circ} \mathrm{C}$ and $280{ }^{\circ} \mathrm{C}$, respectively. Mass detector conditions were: electron impact (EI) mode at $70 \mathrm{eV}$; source temperature: $178{ }^{\circ} \mathrm{C}$; scanning rate: $1 \mathrm{scan} / \mathrm{s}$; mass acquisition: 40-450 amu. One microlitre $(1 \mu \mathrm{l})$ was injected in splitless mode. Carrier gas was helium (1 $\mathrm{mL} / \mathrm{min}$ ).

Separated compounds were identified by their mass spectra and their chromatographic retention times, using commercial products as standards. When the authentic standard was not available, the identification was based on the comparison with the spectral data of Wiley A and NBS75K libraries. The quantification by GC-MS was done using selected $\mathrm{m} / \mathrm{z}$ fragment extracted from the total ion chromatogram for each compound using the internal standard method. Results for non-available compounds were expressed in concentration units $(\mathrm{mg} / \mathrm{L})$ as internal standard equivalents obtained by normalizing the compound peak area to that of the internal standard and multiplying by the concentration of the internal standard.

\section{Sensory analysis}

The wines were evaluated in duplicate by a panel consisting of 10 experienced wine-testers members from Institute of Wine and Vine of Castilla-La Mancha, Spain, with experience in sensory analysis, with age range 25 to 50 years old. Assessment took place in a standard sensory-analysis chamber (ISO $8589,2010)$ equipped with separate booths.

Training was performed over three months in a session per week due to time availability. During training, the judges generated a list of 16 descriptive terms as aroma descriptors of 'Chardonnay' wines.
Throughout the general training, judges discussed about the list and modified it by eliminating, according to judges' consensual decisions, terms they considered irrelevant, ambiguous or redundant and by adding terms they considered pertinent. This initial list was reduced to achieve a list which comprehensively and accurately describes the product space. Finally, 12 olfactive attributes were considered to best describe the aroma characteristics of 'Chardonnay' wine.

Three wines were presented in each session, in coded standard wine-testing glasses according to ISO 87022 (1992) and covered with a watch-glass to minimize the escape of volatile components. The testing temperature of the wine was $10^{\circ} \mathrm{C}$. This temperature is recommended for the consumption of white wine to maintain the balance between sweetness, acidity and alcohol, without affecting the perception of the sensations in the mouth. The panelists used a $10 \mathrm{~cm}$ unstructured scale to rate the intensity of each attribute. The left-hand end of the scale was 'attribute not perceptible' and the right-hand end was 'attribute strongly perceptible'. Fruity (banana, apricot, apple and pineapple), floral, green/fresh and sweet (honey and toffee) were the attributes studied in these wines.

\section{Statistical analysis}

The Student-Newman-Keuls test was applied to discriminate the mean values of chemical data. Statistical processing was carried out by using the SPSS 22.0 for Windows statistical package.

\section{RESULTS AND DISCUSSION}

\section{General composition of wines}

The general composition of 'Chardonnay' wines is shown in Table I.

The three types of wine were produced with the same grape juice and yeast strain, therefore no appreciable differences between the chemical parameters of the wines were found, although it was observed a lower content in succinic acid in DAP wines. These parameters were consistent with a correct elaboration and within the usual values shown by young white wines of the Spanish region of Castilla-La Mancha (García-Romero et al., 2003).

\section{Volatile compounds}

The Table II shows the source, sensory description and odorant series of the aroma compounds in 'Chardonnay' wines obtained in the literature (Etievant, 1991; Guth, 1997; Ferreira et al., 2002; Boido et al., 2003; Peinado et al., 2004; Gómez et al., 2007). 
TABLE I

General composition of 'Chardonnay' wines

Composição geral dos vinhos 'Chardonnay'

\begin{tabular}{|c|c|c|c|}
\hline & Control wine & DAP & Fermaid $O \circledR$ \\
\hline $\begin{array}{l}\text { Glucose+fructose } \\
(\mathrm{g} / \mathrm{L})\end{array}$ & $0.08 \pm 0.00 \mathrm{a}$ & $0.09 \pm 0.01 \mathrm{a}, \mathrm{b}$ & $0.10 \pm 0.01 \mathrm{~b}$ \\
\hline $\begin{array}{l}\text { Ethanol } \\
(\% \mathrm{v} / \mathrm{v})\end{array}$ & $12.47 \pm 0.01 \mathrm{a}$ & $12.52 \pm 0.01 \mathrm{~b}$ & $12.54 \pm 0.00 \mathrm{c}$ \\
\hline $\begin{array}{l}\text { Total acidity* } \\
(\mathrm{g} / \mathrm{L})\end{array}$ & $6.20 \pm 0.05 b$ & $6.19 \pm 0.00 \mathrm{~b}$ & $6.07 \pm 0.02 \mathrm{a}$ \\
\hline pH & $3.22 \pm 0.01 \mathrm{~b}$ & $3.17 \pm 0.01 \mathrm{a}$ & $3.23 \pm 0.01 \mathrm{~b}$ \\
\hline $\begin{array}{l}\text { Volatile acidity } \\
(\mathrm{g} / \mathrm{L})\end{array}$ & $0.28 \pm 0.03 \mathrm{a}$ & $0.26 \pm 0.01 \mathrm{a}$ & $0.27 \pm 0.01 \mathrm{a}$ \\
\hline $\begin{array}{l}\text { L-malic acid } \\
(\mathrm{g} / \mathrm{L})\end{array}$ & $2.89 \pm 0.01 \mathrm{c}$ & $2.71 \pm 0.05 \mathrm{a}$ & $2.79 \pm 0.09 \mathrm{~b}$ \\
\hline $\begin{array}{l}\text { Succinic acid } \\
(\mathrm{g} / \mathrm{L})\end{array}$ & $0.51 \pm 0.04 \mathrm{~b}$ & $0.32 \pm 0.03 \mathrm{a}$ & $0.50 \pm 0.01 \mathrm{~b}$ \\
\hline $\begin{array}{l}\text { Glicerine } \\
(\mathrm{g} / \mathrm{L})\end{array}$ & $6.15 \pm 0.15 \mathrm{~b}$ & $6.27 \pm 0.02 \mathrm{~b}$ & $5.97 \pm 0.10 \mathrm{~b}$ \\
\hline
\end{tabular}

TABLE II

Sensory description and odorant series in 'Chardonnay' wines

Descrição sensorial e séries de odorantes em vinhos 'Chardonnay'

\begin{tabular}{|c|c|c|c|}
\hline Compounds & Source & Sensory description & $\begin{array}{c}\text { Odorant } \\
\text { series* }\end{array}$ \\
\hline Ethyl octanoate & Merck & Sweet, fruity & $1,2,4$ \\
\hline Ethyl hexanoate & Merck & Green apple & 1 \\
\hline$\beta$-damascenone & Extrasynthese & Sweet, fruit & 1,4 \\
\hline Acetaldehyde & Merck & Pungent, ripe apple & 1,5 \\
\hline Isoamyl acetate & Merck & Banana & 1 \\
\hline Ethyl butyrate & Merck & Fruity & 1 \\
\hline Octanoic acid & Merck & Sweat, cheese & 5 \\
\hline Isovaleric acid & Merck & Sweet, acid, rancid & 4,5 \\
\hline Hexanoic acid & Aldrich & Sweat & 5 \\
\hline 3-ethoxy-1-propanol & Aldrich & Fruity & 1 \\
\hline Decanoic acid & Merck & Rancid fat & 5 \\
\hline Ethyl acetate & Merck & Fruity, solvent & 1,5 \\
\hline 3-methyl-1-butanol & Merck & Fusel & 6 \\
\hline Butyric acid & Merck & Rancid, cheese, sweat & 5 \\
\hline 2-phenylethyl alcohol & Aldrich & Floral, roses & 2 \\
\hline$\delta$-dodecalactone & Extrasynthese & Lactone, like-coconut & 4 \\
\hline Ethyl decanoate & Merck & Sweet/fruity & 1,4 \\
\hline 2-phenylethyl acetate & Fluka & Floral & 2 \\
\hline cis-3-hexen-1-ol & Merck & Green, cut grass & 3 \\
\hline Isobutanol & Merck & Oily, bitter, green & 3,5 \\
\hline 4-vinylphenol & Avocado & Almond shell & 6 \\
\hline Furaneol & Aldrich & Burnt sugar, caramel, maple & 4 \\
\hline trans-3-hexen-1-ol & Aldrich & Green & 1,5 \\
\hline$\gamma$-nonalactone & Safc & Coconut & 4 \\
\hline 1-hexanol & Merck & Flower, green, cut grass & 2,3 \\
\hline Guaiacol & Merck & Medicine, sweet, smoke & 4,5 \\
\hline Geraniol & Merck & Roses, geranium & 2 \\
\hline Linalool & Merck & Floral & 2 \\
\hline Isobutyric acid & Merck & Rancid, butter, cheese & 5 \\
\hline
\end{tabular}

As a preliminary step to achieve the identification of the potentially most important wine odorants of studied 'Chardonnay' wines, the odour activity values
$(O A V)$, the ratio between the concentrations of each volatile compound with the corresponding odour threshold was established.

Table III lists the $O A V \mathrm{~s}$ values for the 30 aroma compounds with $O A V>0.1$ obtained in 'Chardonnay' control wines and in 'Chardonnay' wines with different yeasts nitrogen nutrients. The method based in the $O A V$ has been used in the latter years in studies on wine aroma, such as in the discrimination of wines obtained from different grape varieties or characterization of varietal aroma of wines (Guth, 1997; Sánchez-Palomo et al., 2015), in works on accelerated ageing (Moyano et al., 2002; Zea et al., 2007) and in works to studied the influence of different oenological techniques (Sánchez-Palomo et al., 2010). On the basis of their odour description and threshold, the most powerful odorants of 'Chardonnay' wines were tentatively established. Compounds that exhibit $O A V \mathrm{~S}>1$ were considered to contribute individually to the wine aroma and were designated as would-be impact odourants. As can be seen in Table III, a total of 19 compounds exhibited $O A V>1, \quad 7$ esters, 5 acids, 3 alcohols, 2 norisoprenoids, 1 aldehyde and 1 lactone in all wines independently of nutrient employed in the winemaking process. On the other hand, the control wines present almost all cases lower $O A V \mathrm{~s}$ than the wines obtained by musts supplemented with DAP and Fermaid $O{ }^{\circledR}$ nitrogen nutrient. From a theoretical point of view, the remaining compounds not directly contributed to the aroma profile $(O A V<1)$, although some authors consider that they can enhance some notes already present because of synergistic effects with other odorant compounds (Freitas et al., 1999; López et al., 1999).

It is difficult to predict the overall aroma impact of these wines from the sheer size of the data. To estimate overall wine aroma, the odour descriptors were grouped in different aromatic series and every compound is assigned to one or several aromatic series based on similar odour descriptor used. The series used in this work grouped compounds with similar odour descriptors and represent the main constituents of the aroma profile of the wine: fruity, floral, green/fresh, sweet, fatty and other odours. Because of the high complexity of olfactive perceptions, some aroma compounds were included in two or more odorant series according to the findings of some authors (Charles et al., 2000; Zea et al., 2007) as shows in Table II. Nevertheless, as odour thresholds are affected by additive, synergic and antagonistic effects of the volatile compounds in a matrix, the identification of the most powerful odorants only on the basic of their $O A V$ values should be considered as a tentative. 


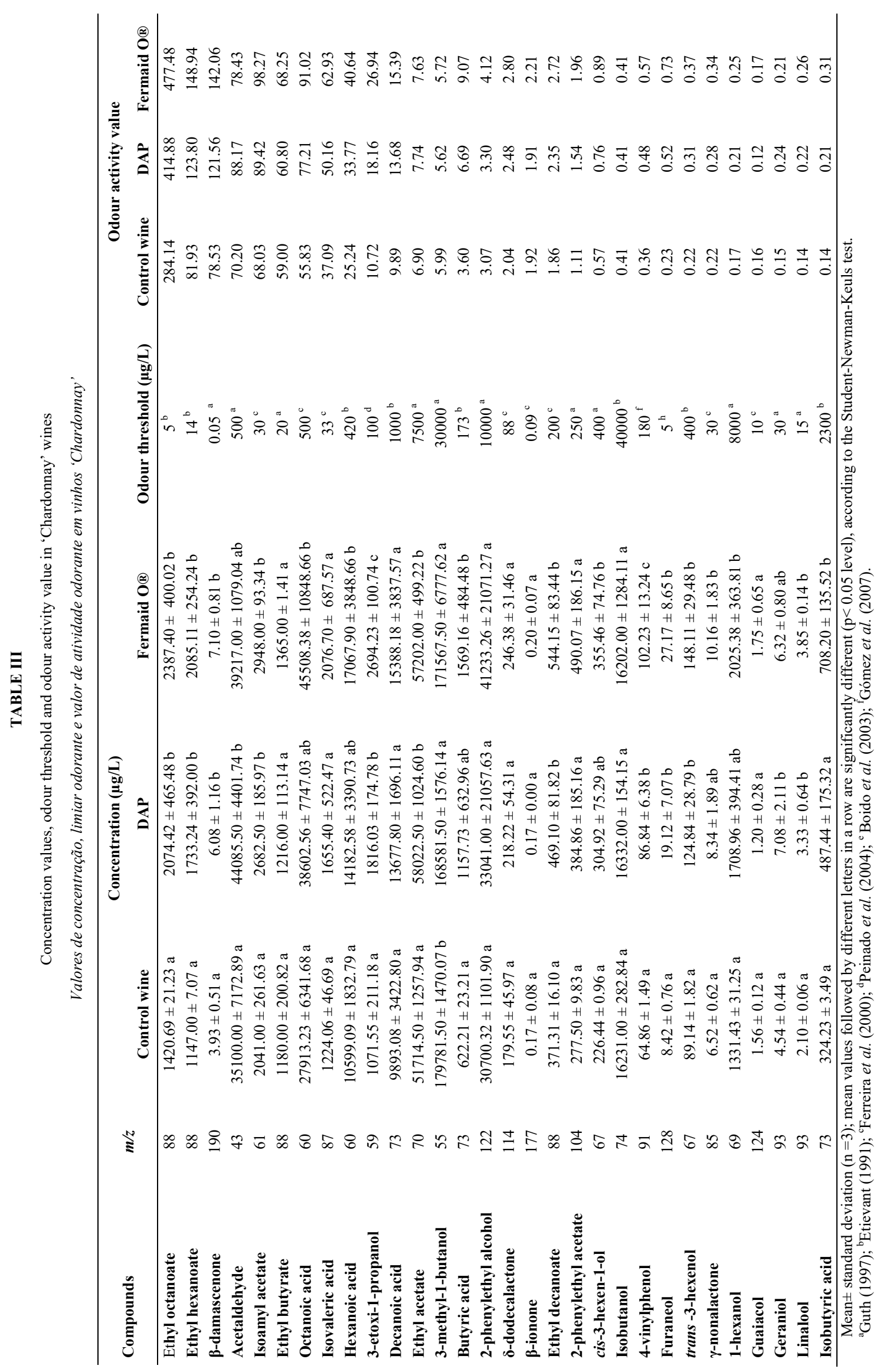


The total intensities for every aromatic series were calculated as sum of the $O A V$ of each one of the compounds assigned to this series and the results were graphed in Figure 1. This procedure makes it possible to relate quantitative information obtained by chemical analysis to sensory perception, providing a single aroma profile. Intensity patterns in the category suggest that the major aroma characteristic of these wines would consist principally of fruity, floral and sweet.

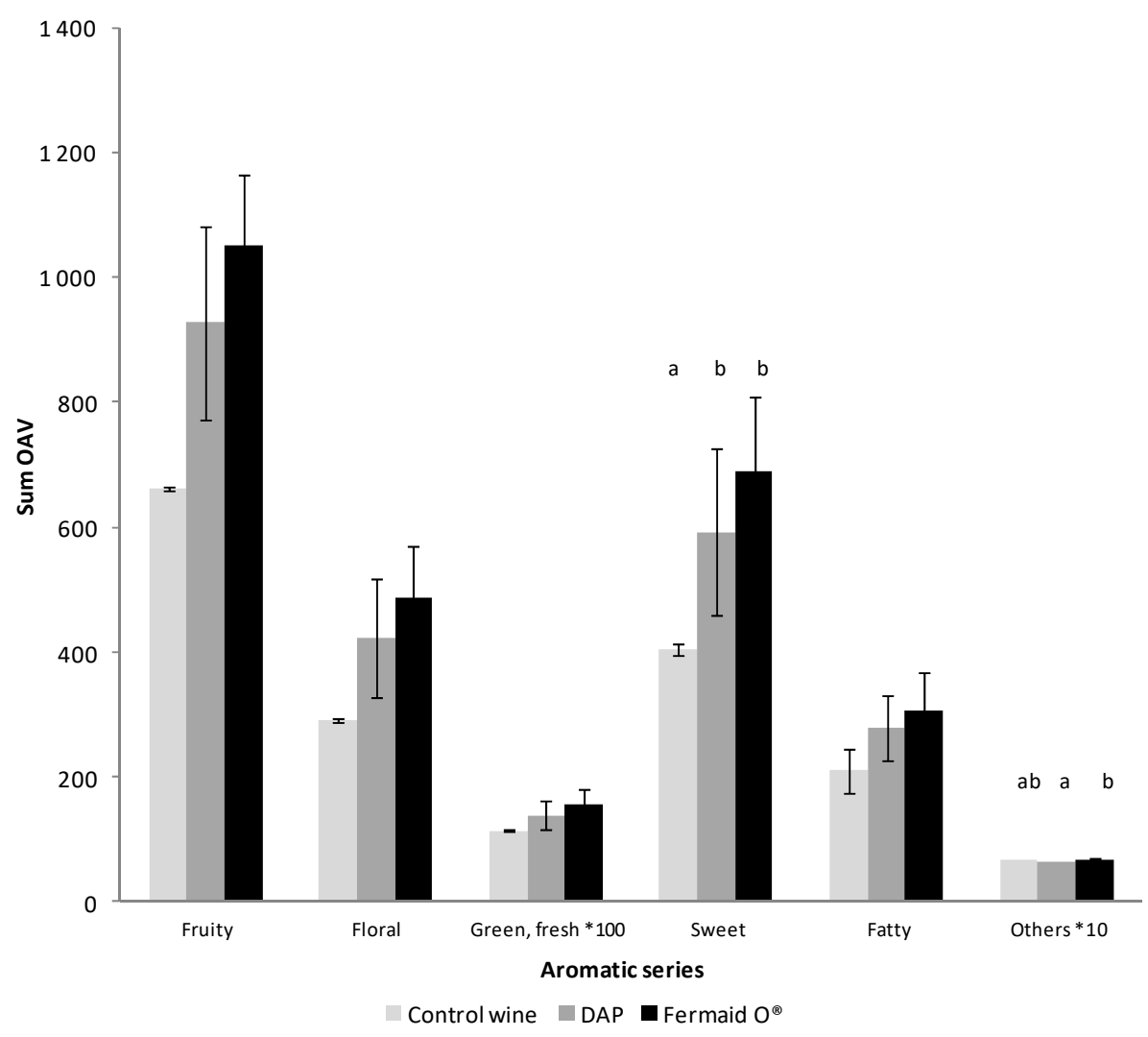

Figure 1. Aromatic series in 'Chardonnay' wines.

Séries aromáticas em vinhos 'Chardonnay'.

According to the results shown in Figure 1, it can be observed that the aromatic series fruity, floral, and sweet showed a great intensity in the aroma profile of 'Chardonnay' studied wines. Higher values were found in the wines obtained by supplemented must, especially when the nutrient used is Fermaid $O \circledR$. On the other hand, the aromatic series green/fresh and fatty were the minor aroma categories, although their importance in the sensory profile. This can be due to the fact that the total intensity values in the different aromatic series were obtained as sum of the individual $O A V \mathrm{~s}$ of each of the components without considering the rest of the compounds present in the wine matrix. Nevertheless when combined, synergy, suppression and matrix effects may alter the intensity of the descriptors, masking the descriptors of some aromatic series (fatty) and increasing the intensity of others odour descriptors (green/fresh and floral). These results are in agreement with those obtained by Gürbüz et al. (2006) in red wines made from 'Merlot' and 'Cabernet Sauvignon' grape varieties (SánchezPalomo et al., 2010).

As odour thresholds are affected by high imprecision and synergic, additive and antagonistic effects can take place, these values should not be taken as closed boundaries but as an approximation to the number of odorants that constitute the odour of such wines. There was a great similarity among the wines studied. 
The most potent odorants of each wine are practically the same, only changing the relative order from one sample to another.

Differencing components are those that have a more acute role in the perception of sensory differences between wines. At the present time, this property can only be verified by means of sensory tests, although an approximation can be obtained by considering the variability in geometric terms of concentration or of concentrations normalized by their threshold $(O A V)$ (López et al., 2003).

This approximation is explained in Table IV.

\section{TABLE IV}

Determination of OAV max/OAV min in the aroma compounds of the three types of wine studied

Determinação de OAVmax /OAVmin para os compostos do aroma dos três tipos de vinho estudados

\begin{tabular}{|c|c|}
\hline Compounds & $O A V \max / O A V \min$ \\
\hline Furaneol & 3.23 \\
\hline Butyric acid & 2.52 \\
\hline 3-etoxi-1-propanol & 2.51 \\
\hline Isobutyric acid & 2.18 \\
\hline Linalool & 1.83 \\
\hline Ethyl hexanoate & 1.82 \\
\hline$\beta$-damascenone & 1.81 \\
\hline 2-phenylethyl acetate & 1.77 \\
\hline Isovaleric acid & 1.70 \\
\hline Ethyl octanoate & 1.68 \\
\hline trans-3-hexenol-1-ol & 1.66 \\
\hline Octanoic acid & 1.63 \\
\hline Hexanoic acid & 1.61 \\
\hline 4-vinylphenol & 1.58 \\
\hline cis-3-hexen-1-ol & 1.57 \\
\hline Geraniol & 1.56 \\
\hline$\gamma$-nonalactone & 1.56 \\
\hline Decanoic acid & 1.56 \\
\hline 1-hexanol & 1.52 \\
\hline Ethyl decanoate & 1.47 \\
\hline Guaiacol & 1.46 \\
\hline Isoamyl acetate & 1.44 \\
\hline$\partial$-dodecalactone & 1.37 \\
\hline 2-phenylethyl alcohol & 1.34 \\
\hline Acetaldehyde & 1.26 \\
\hline$\beta$-ionone & 1.16 \\
\hline Ethyl butyrate & 1.16 \\
\hline Ethyl acetate & 1.12 \\
\hline 3-methyl-1-butanol & 1.07 \\
\hline Isobutanol & 1.00 \\
\hline
\end{tabular}

This table shows the group of aroma compounds capable to introduce differences in the three types of wines studied. The value of the ratio $O A V \max / O A V$ min was calculated in order to know which compounds are responsible for the increase the differences in the final aroma of the three types of wine studied.

From these results, some important conclusions can be obtained. The first group is made up of the components with an $O A V \max / O A V$ min ratio $>2$. This group includes furaneol, butyric acid, 3-etoxi-1propanol and isobutyric acid. Furaneol is normally related to aromas with notes of burnt sugar, caramel and maple (Genovese et al., 2005). Butyric and isobutyric acid are two of the most important compounds formed during the alcoholic fermentation, therefore these compounds have not relation with the grape variety used in the winemaking process (Ferreira et al., 1998; Hernández-Orte et al., 2002).

The second group is principally formed of the aromas generated in the metabolism of fatty acids by yeasts and by certain varietal compounds such terpene compounds and C13-norisoprenoids. Some of these compounds have high $O A V \mathrm{~s}$, but the maximum/minimum $O A V$ ratio is well below 2, which confirms that the influence of must supplementation with inorganic and organic nitrogen on synthesis of these compounds has a secondary importance, because these compounds are mainly associated with the varietal differentiation.

\section{Sensory analysis}

Table V shows the most relevant attributes of aroma sensory profile of 'Chardonnay' studied wines. According to the result of sensory analysis, aroma sensory profile of 'Chardonnay' control wines was characterized by great intensity of banana, apple, pineapple, apricot, floral and green/fresh attributes, with notes of honey and toffee. The supplementation of must with inorganic nitrogen, and particularly with organic nitrogen, caused a significant increase of attributes detected in control wines. 
TABLE V

Mean aroma attribute scores of 'Chardonnay' wines according to the sensory trials

Valores médios dos atributos do aroma dos vinhos 'Chardonnay' de acordo com os testes sensoriais

\begin{tabular}{llll}
\hline Attributes & Control wine & DAP & Fermaid O® \\
\hline Aroma intensity & $6.15 \pm 0.15 \mathrm{a}$ & $7.15 \pm 0.32 \mathrm{~b}$ & $7.45 \pm 0.04 \mathrm{~b}$ \\
Fruity & $5.75 \pm 0.09 \mathrm{a}$ & $6.68 \pm 0.03 \mathrm{ab}$ & $7.23 \pm 0.04 \mathrm{c}$ \\
Banana & $2.17 \pm 0.14 \mathrm{a}$ & $4.68 \pm 0.54 \mathrm{~b}$ & $6.86 \pm 0.98 \mathrm{c}$ \\
Apricot & $6.17 \pm 0.34 \mathrm{a}$ & $4.21 \pm 0.41 \mathrm{~b}$ & $4.01 \pm 0.21 \mathrm{~b}$ \\
Apple & $6.20 \pm 0.05 \mathrm{a}$ & $4.19 \pm 0.10 \mathrm{~b}$ & $4.07 \pm 0.12 \mathrm{~b}$ \\
Pineapple & $2.82 \pm 0.31 \mathrm{a}$ & $3.91 \pm 0.17 \mathrm{ab}$ & $4.75 \pm 0.42 \mathrm{~b}$ \\
Floral & $4.12 \pm 0.23 \mathrm{a}$ & $6.21 \pm 0.47 \mathrm{~b}$ & $7.82 \pm 0.34 \mathrm{c}$ \\
Green & $2.89 \pm 0.01 \mathrm{~b}$ & $1.71 \pm 0.05 \mathrm{a}$ & $4.79 \pm 0.09 \mathrm{c}$ \\
Fresh & $3.71 \pm 0.04 \mathrm{~b}$ & $2.01 \pm 0.03 \mathrm{a}$ & $4.99 \pm 0.01 \mathrm{c}$ \\
Sweet & $1.56 \pm 0.49 \mathrm{a}$ & $6.61 \pm 0.04 \mathrm{~b}$ & $7.83 \pm 0.04 \mathrm{c}$ \\
Honey & $1.71 \pm 0.24 \mathrm{a}$ & $3.32 \pm 0.28 \mathrm{~b}$ & $3.68 \pm 0.74 \mathrm{~b}$ \\
Toffee & $6.15 \pm 0.15 \mathrm{a}$ & $6.22 \pm 0.02 \mathrm{a}$ & $5.97 \pm 0.10 \mathrm{a}$ \\
\hline
\end{tabular}

Mean \pm standard deviation $(n=3)$; mean values followed by diiferent letters in a row are significantly different $(\mathrm{p}<0.05$ level), according to the Student-Newman-Keuls test; mean $=0$, attribute not perceptible; mean= 10, attribute strongly perceptible.

\section{CONCLUSIONS}

The fruity and sweet series are those that present greater contribution to the aromatic profile of 'Chardonnay' wines, regardless of the nitrogen sources added. The floral and green series, in combination, contribute in low proportion, although these attributes are the most characteristic of the sensorial profile. This may result from the fact that the total intensity values in the different aromatic series were obtained as sum of the individual OAVs of each component without taking into account the rest of the compounds present in the wine matrix.

\section{REFERENCES}

Albers E., Larsson C., Liden G., Niklasson C., Gustafsson L. 1996. Influence of the nitrogen source on Saccharomyces cerevisiae anaerobic growth and product formation. Appl. Environ. Microbiol, 62, 3187-3195.

Barbosa, C., Mendes-Faia, A., Mendes-Ferreira, A. 2012. The nitrogen source impacts major volatile compounds released by Saccharomyces cerevisiae during alcoholic fermentation. Int. J. Food Microbiol., 160, 87-93.

Bely M., Sablayrolles J.M., Barre P. 1990. Automatic detection of assimilable nitrogen deficiencies during alcoholic fermentation in oenological conditions. . J. Ferment. Bioeng, 70, 246-252.
The fortification of must with nitrogen enhanced the aromatic complexity of wines, increasing significantly the intensity of the sensory attributes of the control wines, especially when the nitrogen source was organic (Fermaid $\mathrm{O}^{\circledR}$ ).

\section{ACKNOWLEDGMENTS}

P. M. Izquierdo-Cañas is grateful to the INCRECYT program and the European Social Fund for financial support.

Bisson L.F. 1991. Influence of nitrogen on yeast and fermentation of grapes. In: Proceedings of the International Symposium on Nitrogen in Grapes and Wine. Am. Soc. Enol. Vitic. Davis 78-89.

Boido E., Lloret A., Medina K., Fariña L., Carrau F., Versini G., Dellacassa E. 2003. Aroma composition of Vitis vinifera cv. Tannat: the typical red wine from Uruguay. J. Agr. Food Chem., 51(18), 5408-5413.

Burin, V. M., Gomes, T. M., Caliari, V., Rosier, J .P, Bordignon Luiz, M. T. 2015. Establishment of influence the nitrogen content in musts and volatile profile of white wines associated to chemometric tools. Microchemical Journal, 122, 20-28.

Butzke C. 1998. Survey of yeast assimilable nitrogen status in musts from California, Oregon, and Washington. Am. J. Enol. Vitic, 49, 220-224. 
Charles M., Martin B., Ginies C., Etievant P., Coste G., Guichard E. 2000. Potent aroma compounds of two red wine vinegars. $J$. Agric. Food Chem., 48, 70-77.

Etievant P.X., 1991. Wine. In: Volatile Compounds in Foods and Beverages. 483-587. Marse H. (ed), Marcel Dekker Inc., New York.

Ferreira V., López R., Cacho J. 2000. Quantitative determination of the odorants of young red wines from different grape varieties. $J$. Sci. Food Agric., 80, 1659-1667.

Ferreira V., Lopez R., Escudero A., Cacho J. 1998. The aroma of Grenache red wine: Hierarchy and nature of its main odorants. $J$. Sci. Food Agric., 77, 259-267.

Freitas V., Ramalho P., Azevedo Z., Macedo A. 1999. Identification of some volatile descriptors of the rock-rose-like aroma of fortified red wines from Douro demarcated region. $J$. Agric. Food Chem., 47, 4327-4331.

García-Romero E., Chacón J.L., Martínez J., Izquierdo-Cañas PM. 2003. Changes in volatile compounds during ripening in grapes of Airén, Macabeo and Chardonnay white varieties grown in La Mancha region (Spain). Food Sci. Technol. Inter., 9, 33-41.

Garde-Cerdán T., Ancín-Azpilicueta C. 2008. Effect of the addition of different quantities of amino acids to nitrogen-deficient must on the formation of esters, alcohols, and acids during wine alcoholic fermentation. LWT-Food Sci. Technol., 41, 501-510.

Genovese A., Piombino P., Lisauti M.T., Moio L. 2005. Ocurrence of furaneol (4-hydroxy-2,5-dimethyl-3(2H) Furanone in some wines from Italian native grapes. Ann. Chim., 95, 415-419.

Gómez M.J., Cacho J.F., Ferreira V., Vicario I.M., Heredia F.J. 2007.Volatile components of Zalema white wines. Food Chem., 100, 1464-1473.

Gürbüz O., Rouseff J.M., Rouseff R.L. 2006. Comparison of aroma volatiles in commercial Merlot and Cabernet Sauvignon wines using gas chromatography-olfactometry and gas chromatographymass spectrometry. J. Agric. Food Chem., 54, 3990-3996.

Guth H. 1997. Quantification and sensory studies of character impact odorants of different white wine varieties. J. Agric. Food Chem., 45, 3027-3032.

Hernández-Orte P., Bely M., Cacho J., Ferreira V. 2006. Impact of ammonium additions on volatile acidity, ethanol, and aromatic compound production by different Saccharomyces cerevisiae strain during fermentation in controlled synthetic media. Aust. J. Grape Wine. Res., 12, 150-160.

Hernández-Orte P., Cacho J.F., Ferreira V. 2002. Relationship between varietal amino acid profile of grapes and wine aromatic composition. Experiences with model solutions and chemometric study. J Agric. Food Chem., 50, 2891-2899.

Ibarz M., Ferreira V., Hernández-Orte P., Loscos N., Cacho J. 2006. Optimization and evaluation of a procedure for the gas chromatographic-mass spectrometric analysis of the aromas generated by fast acid hydrolysis of flavors precursors extracted from grapes. J. Chromatogr. A, 1116, 217-229.
ISO 8589, 2010. Análisis Sensorial. Guía general para el diseño de sala de cata. In: Análisis Sensorial. 53-76. AENOR (Ed), Madrid.

ISO 87022, 1992. Análisis Sensorial. Utensilios. Copa para la degustación de vino. In: Análisis Sensorial. 77-80. AENOR (Ed), Madrid.

Izquierdo-Cañas P.M., García-Romero E., Heras-Manso J.M., Fernández-González M. 2014. Influence of sequential inoculation of Wickerhamomyces anomalus and Saccharomyces cerevisiae in the quality of red wines. Eur. Food Res. Technol., 239, 279-286.

Lopez R., Ferreira V., Hernández P., Cacho J. 1999. Identification of impact odorants of young red wines made with Merlot, Cabernet Sauvignon and Grenache grape varieties: a comparative study. $J$. Sci. Food Agric., 79, 1461-1467.

Lopez R., Ortin N., Perez-Trujillo J.P., Cacho J., Ferreira V. 2003. Impact odorants of different white wines from the Canary Islands. J. Agric. Food Chem., 51, 3419-3425.

Moyano L., Zea L., Moreno J., Medina M. 2002. Analytical study of aromatic series in sherry wines subjected to biological ageing. $J$ Agric. Food Chem., 50, 7356-7361.

OIV, 2014. Compendium of international methods of wine and must analysis. 277 p. International Organisation of Vine and Wine, Paris.

Peinado R.A., Moreno J., Medina M., Mauricio J.C. 2004. Changes in volatile compounds and aromatic series in sherry wine high gluconic acid levels subjected to aging by submerged flor yeast cultures. Biotechnol. Lett. 26, 757-762.

Sánchez-Palomo E., Gómez García-Carpintero E., Alonso-Villegas R., González-Viñas M. A. 2010. Flavour Fragr. J., 25 (6), 456-462.

Sánchez-Palomo E., Gómez-García-Carpintero E., González-Viñas MA. 2015. Aroma Fingerprint Characterisation of La Mancha Red Wines. S. Afr. J. Enol. Vitic., 36 (1): 117-125.

Sánchez-Palomo, E., Pérez-Coello, M. S., Díaz-Maroto, M. C., González-Viñas, M. A., Cabezudo, M. D. 2006. Contribution of free and glycosidically-bound volatile compounds to the aroma of muscat "a petit grains" wines and effect of skin contact. Food Chem., 95, 279-289.

Torrea, D., Varela, C, Ugliano, M., Ancin-Azpilicueta, C., Leigh Francis, I., Henschke, P.A. 2011. Comparison of inorganic and organic nitrogen supplementation of grape juice -Effect on volatile composition and aroma profile of a Chardonnay wine fermented with Saccharomyces cerevisiae yeast. Food Chem., 127, 10721083.

Vilanova M., Ugliano-Varela C., Siebert T., Pretorius I.S., Henschke PA. 2007. Assimilable nitrogen utilisation and production of volatile and non-volatile compounds in chemically defined medium by Saccharomyces cerevisiae wine yeasts. Appl. Microbiol. Biotechnol., 77,145-157.

Zea L., Moyano L., Moreno J., Medina M. 2007. Aroma series as fingerprints for biological ageing in fino sherry-type wines. $J$. Sci. Food Agric., 87, 2319-2326. 